\title{
The Opportunity, Challenge and Strategy of MOOC Bringing to Ideological and Political Theory Course in Colleges*
}

\author{
Jikun Wang \\ Jilin Agricultural Science and Technology University \\ Jilin, China 132101
}

\author{
Lujun $\mathrm{Lv}^{* *}$ \\ Jilin Agricultural Science and Technology University \\ Jilin, China 132101 \\ **Corresponding Author
}

\begin{abstract}
Since 2012, the world has set off a wave of "MOOC". With the addition of Tsinghua University and other universities, MOOC has rapidly developed in China. This brings some opportunities to the course construction of ideological and political theory in Chinese to a certain extent but also brings some challenges. The course of ideological and political theory is the key course of enhancing morality and fostering talents. Therefore, authors need to understand MOOC and the construction of ideological and political theory courses in universities in China correctly. And on this basis, authors clarify the positive and negative impact of the course on the curriculum construction of ideological and political theory in China and explore the curriculum system of ideological and political theory course with Chinese characteristics and China's actual national conditions to enhance the affinity and pertinence of the course construction of ideological and political theory courses in universities.
\end{abstract}

Keywords-MOOC; ideological and political theory course; opportunity; challenge

\section{INTRODUCTION}

In the School Teachers' Symposium on ideological and political theory, General Secretary Xi Jinping pointed out: "To promote the reform and innovation of ideological and political theory course, it is necessary to constantly enhance the ideological, theoretical and affinity and relevance of the course of thought and political theory." MOOC, as a new teaching method, has played a certain role in promoting the affinity and pertinence of ideological and political theory courses in colleges in a certain extent. On the other hand, it has also brought some challenges to the construction of ideological and political theory courses in universities. This paper starts with the basic concepts of the course of ideological and political theory and MOOC. Combining with China's national conditions, this paper analyzes the opportunities and challenges that MOOC brought to the ideological and political theory course of universities in China, and explores the construction of the curriculum

*Project: In this paper, the research was sponsored by Jilin Agricultural Science and Technology University Ideological and Political Special Project "Research on improving affinity and pertinence of ideological and political courses in colleges and universities based on MOOCs" (Project No. 20190327). system of ideological and political theory courses with Chinese characteristics, and enhances the relevance and affinity to complete the fundamental task of enhancing morality and fostering talents.

\section{RESEARCH ON THE BASIC THEORY OF MOOC AND IDEOLOGICAL AND POLITICAL THEORY COURSE}

Clarifying the basic concept is the premise and foundation of the research. It is necessary to clarify the meaning and characteristics of MOOC and the ideological and political theory course before carrying out the research. And on this basis, authors analyze the opportunities and challenges brought by MOOC bringing to the construction of the ideological and political theory course in China.

\section{A. The Meaning and Characteristics of MOOC}

"MOOC is an acronym for Massive Open online Course, which literally means large-scale online open courses. A large scale means that students are large in size and large in data; openness means that curricula and teaching resources are open to all, not limited to specific users; online means that the acquisition and completion process is achieved online through the network, primarily or all of the teaching links [1].

From this, it can be seen that MOOC has the characteristics of large-scale, open and community as the activity unit. Among them, community activities refers to the process of learning in the course, the teacher will divide the students into several groups, through group discussions and other forms to promote the exchange of members within the group. At the same time, through the form of group cooperation to complete the task, it cultivates the students' sense of cooperation and independent thinking ability.

\section{B. The Meaning of the Course of Ideological and Political Theory}

The course of ideological and political theory is referred to as the course of thought and politics, as a compulsory course for college students, plays an important role in the learning process of college students and is an important course for students to carry out world Outlook, Outlook on 
life and values education, and for different levels of schools, the content of the courses offered is not the same. Among them, higher vocational colleges set up "Ideological and Moral Cultivation and legal Basis" and "Introduction to Mao Zedong Thought and the Theoretical System of Socialism with Chinese Characteristics", the undergraduate colleges and universities set up "Ideological and Moral Cultivation and legal Basis", "Outline of Modern Chinese History", "Introduction to the Basic Principles of Marxism", " An Introduction to Mao Zedong Thought and the Theoretical System of Socialism with Chinese Characteristics and the Situation and Policy five courses. Graduate students and Doctoral students each set a compulsory course. Through the study of these courses, students can understand the modern history of Chinese, the basic national conditions and routes, policies and principles of contemporary China, as well as Marxism, and educate college students on their values, so as to help them establish a correct world outlook, Outlook on life, values. Then it trains the builders and successors of the socialist cause of comprehensive development in line with the requirements of the State.

\section{THE OPPORTUNITY OF MOOC BRINGING TO THE CURRICULUM CONSTRUCTION OF IDEOLOGICAL AND POLITICAL THEORY COURSE IN UNIVERSITIES}

As a new teaching carrier, MOOC has played a certain role in promoting the construction of ideological and political theory course and mobilizing students' enthusiasm and initiative in learning ideological and political theory course. The opportunity of MOOC bringing to the curriculum construction of ideological and political theory course in universities is mainly embodied in: firstly, to show the main position of students in teaching; secondly, to promote the innovation and development of the teaching method of ideological and political theory course, and thirdly, to advance the innovation of teaching carrier of ideological and political theory course.

The first is to highlight the main position of students in teaching. Unlike traditional ideological and political theory courses in the past, the ideological and political theory course of MOOC pays more attention to the main position of students in the teaching of ideological and political theory, and the teachers will adjust the teaching contents and methods according to the specific situation of the students, and then arouse the enthusiasm and initiative of the students to study the ideological and political theory course. Compared with the course construction of traditional ideological and political theory, the ideological and political theory course of MOOC divides a certain core problem into several levels, through a comprehensive and detailed explanation of this problem, so that students can fully understand and master the knowledge, through the segmented small video teaching. In a certain extent, it alleviates the situation that students can't concentrate on listening or lack of macroscopic overall grasp of the knowledge they have learned, and more respect for the subject status of students in teaching.
Second, it is beneficial to the innovation and development of the teaching method of ideological and political theory course in universities

As a new teaching method, the combination of the course of ideological and political theory can make up for the shortcomings of the traditional teaching methods of ideological and political theory, and realize the organic combination between teaching and learning, classroom and class, the first classroom and the second classroom, and in a certain extent, it is beneficial to enhance the relevance and affinity of the construction of ideological and politics courses

The application of MOOC to the construction of ideological and political theory course enriches and develops the teaching method of traditional ideological and political theory course $t$ and can arouse students' enthusiasm and initiative in learning ideological and political theory course by carrying out heuristic teaching and problem teaching to students, and use group teaching. It has a very important role in the cultivation of students' cooperative consciousness and collective consciousness and the promotion of students' comprehensive quality.

The third is to promote the innovation of teaching carrier in ideological and political theory course in universities. "Carrier means something in science and technology that transmits energy or carries other substances or generally refers to something that can carry other things".[2]. In his speech at the School Teachers' symposium on ideological and political theory, General Secretary Xi Jinping pointed out that the course of ideological and political theory is the key course to implement the fundamental task of enhancing morality and fostering talents. Facing the rapidly changing environment at home and abroad, it is necessary to attach importance to the innovation construction of the teaching carrier of ideological and political theory course, enrich the teaching carrier form of ideological and political theory course, and put the ideological and political education through the whole process of teaching.

As a kind of mass communication carrier of ideological and political education, MOOC plays an important role in the carrier innovation of ideological and political theory course construction. Through the MU course platform, educators transmit the content of ideological and political education to the educated, so that students carry out ideological and political education to the educated, guide the students to establish a correct world outlook, Outlook on life and values, and then enhance the ideological and moral quality of the educated, while making extensive contact with the social information.

\section{THE CHALLENGE OF MOOC BRINGING TO THE CURRICULUM CONSTRUCTION OF IDEOLOGICAL AND POLITICAL THEORY COURSE IN UNIVERSITIES}

Because of the borderless nature of the Internet, the educated will be influenced by various ideas or thoughts in the process of learning. At the same time, the western hostile forces have never stopped infiltrating and invading the ideological field of Chinese. Therefore, it will be necessary 
to adhere to China's position, correctly judge and reflect on the ideological and political theory course of MOOC, correctly understand the challenges brought by the course of ideological and political theory, and then explore the curriculum construction system of the ideological and political theory course with Chinese characteristics suitable for China's national conditions, and promote the construction of ideological and political theory course in colleges and universities

At present, the challenge of MOOC bringing to the construction of ideological and political theory course in universities is mainly embodied in the following three aspects: firstly, MOOC brings impact on the teaching content of ideological and political theory course in universities, and secondly, MOOC brings impact on the mode of ideological and political theory course in c universities. Thirdly, MOOC brings impact on teachers of ideological and political theory course.

First, MOOC brings impact on the teaching content of ideological and political theory course in universities .At present, the course of "MOOC" is still dominated by Western universities, and the "universal values" it promotes are not in line with the core values of socialism that it be advocated, and the values it advocates have a strong ideological tinge, and for students who do not yet have the values advocated by the West to accurately judge, It is easy to be influenced by the values it promotes and preaches, and then weakens the political identity of young people's socialist core values and the socialist system of Chinese, which is not conducive to the construction of ideological and political theory courses in universities in China. The challenge to the teaching content of ideological and political theory course in universities in China is not only embodied in the challenge of the main content of socialist core values, but also in the challenge to the security of mainstream ideology in China. Because of the international nature of the Internet, various social trends of thought spread through the internet, such as historical nihilism by distorting historical facts, advocating Western values, and then influencing the teaching content of ideological and political theory courses in universities in China, which is not conducive to the dissemination of the teaching content of mainstream ideological and political theory courses.

Second, MOOC brings challenges to the teaching mode of ideological and political theory course. The traditional teaching mode takes the teacher as the main body, its teaching adopts the "one-to-many", a teacher will face more students, because of the limitation of time and space, the teacher can't communicate effectively with the students, which leads to the students' enthusiasm and initiative in learning ideological and political theory course in a certain extent. The teaching mode of ideological and political theory, which takes MOOC as the carrier, relies on big data to alleviate the problem of poor communication between teachers and students, but at the same time, because of the large number of students in the course selection, teachers or teaching assistants can't answer all the questions of students' questions one by one, resulting in a large number But the problem of having a smaller number of people actually completing the selected course of study. The great contrast between the high class selection rate and the low completion rate reflects the instability and transient nature of the teaching mode of the MOOC.

Third, MOOC brings challenges to teachers of ideological and political theory course. MOOC not only challenges the teaching content and teaching mode of ideological and political theory course, but also brings challenges to the teachers of ideological and political theory course to a certain extent. The challenges brought by MOOC to teachers of ideological and political theory are mainly embodied in: Firstly, because MOOC relies on the big data platform, compared with the traditional ideological and political theory course teaching, its coverage is broader and larger, which leads to some ideological and political theory teachers may face the challenge of elimination or transfer; Secondly, as a product of the internet age, MOOC is more demanding on the ability to use Internet technology, which challenges the information literacy of teachers of ideological and political theory and the ability to use Internet technology in all aspects to a certain extent; Thirdly, relying on the big data platform of the MOOC, compared to the traditional ideological and political theory teaching, teachers and students between the relatively more communication, to promote the communication between students and teachers at the same time, but also will test the teacher's overall grasp of knowledge and reserves, which requires teachers to pay more attention to knowledge and learning to master, exercise their ability to adapt, to meet the learning needs of students.

\section{CONSTRUCTION OF IDEOLOGICAL AND POLITICAL THEORY COURSES OF MOOC IN UNIVERSITIES WITH CHINESE CHARACTERISTICS}

At present, the practice strategy of ideological and political theory course construction in universities to deal with the challenge of MOOC is mainly from the following aspects: firstly, strengthen the standardization and guidance of the Internet environment, purify the Internet environment, create a good external environment for the organic combination of the Internet and education, guard against the input and penetration of Western values, and safeguard China's ideological. Secondly, innovating the curriculum model of ideological and political theory course, exploring the course of ideological and political theory with "SPOC" as the main mode, on the basis of the experience of absorbing the thought course in the curriculum construction of theoretical courses, and improving the shortcomings in the construction of the ideological and political theory course of MOOC based on the actual situation, To build the course and platform of "MOOC" with high efficiency ideological and political theory course with Chinese characteristics, and thirdly, to innovate the teaching method of ideological and political theory course in universities to combine classroom teaching with extracurricular teaching. Finally is to promote the media accomplishment and comprehensive quality of teachers in ideological and political theory. 


\section{A. Safeguarding China's Ideological Security Based on China's National Conditions}

As a product of the Western world, most of the courses in the current Coursera, edX and Udacity three Bermuda platforms are produced by Western countries, and their values are mostly those pursued and advocated by Western society. In a certain extent, this has increased the input of Western values into China, which is not conducive to maintaining China's ideological security. Therefore, it is necessary to take corresponding measures to deal with the impact of MOOC on the ideological field of Chinese. Related departments strengthen the supervision of network security and the leading ideology of social mainstream.

Whether the ideological prominence of ideological and political theory course is prominent or not is a major issue concerning the correctness of students' thinking. Therefore, in the process of carrying out the curriculum construction of the ideological and political theory course, it is necessary to strengthen the guidance to the students, adhere to the socialist core values as the guide, based on China's basic national conditions, from the students' teaching practice, tell the Chinese story, and spread the Chinese voice. It will also be necessary to correctly handle the relationship between traditional culture and socialist culture, reasonably absorb the excellent resources in traditional culture, constantly enrich and develop the socialist culture with Chinese characteristics, and enhance the Chinese nation's road self-confidence, theoretical self-confidence, institutional self-confidence and cultural self-confidence.

\section{B. Actively Exploring the Curriculum Construction Model of Ideological and Political Theory Course with "SPOC"}

As the main mode SPOC is an abbreviation for English Small Private online Course, which, in its literal sense, is understood as "a small-scale limited on-line course." It is generally believed that the concept was first used by Professor Armando Fox."[3] Compared with the large-scale and open in MOOC, small-scale refers to the size of elective students more than hundreds of people, "Private" refers to the students to set restrictive access conditions, only to meet the requirements of the standard students, can enter the SPOC curriculum learning.

SPOC model, as a mixture of classroom teaching and MOOC teaching mode, combines the reasonable factors in traditional teaching with the advantage conditions in the teaching of MOOC, and at the same time, through the use of certain ways and means to make up for the shortcomings in the traditional teaching and teaching mode, And then promote the university ideological and political theory course construction effectiveness and targeted promotion. The application of SPOC model to the curriculum construction of ideological and political theory course in universities should firstly, adhere to people-oriented, respect the subject status of the educated in the teaching process, follow the law of ideological and political work, the law of teaching and educating people and the law of Students' growth, and formulate different teaching schemes according to the students' learning practice; secondly, Taking the big data platform as the technical support and then improving the overall effect of the course construction of ideological and political theory courses, finally, the teaching method of innovating ideological and political theory course makes the classroom teaching and extracurricular teaching combine organically, carries on the correct value guidance to the student, creates the high efficiency ideological and political theory course network construction new mode.

\section{Innovative Teaching Methods to Integrate Classroom Teaching with Extracurricular Teaching}

The project-oriented research based on the problem, based on China's national conditions, carries out systematic combination of theory and practice, and provides support for the course construction of ideological and political theory from the theoretical aspects. In his speech at the School Teachers' Symposium, General Secretary Xi Jinping pointed out: "We should adhere to the unity of theory and practicality, cultivate people with scientific theory, attach importance to the practicality of the course of thinking and politics, combine the small classroom of thinking and politics with the social classroom, and educate and guide students to set ambitions and struggle." [4] It will be of great significance to constantly improve the relevance and affinity of the course of ideological and political theory.

\section{CONCLUSION}

This paper tries to take the "SPOC" as the main mode of the ideological and political theory curriculum construction model, on the basis of the study of the MOOC, to draw on the positive role played by the course in the process of ideological and political course construction, and at the same time Based on China's national conditions, it is necessary to explore the curriculum construction system and curriculum of the ideological and political theory course of mu course with Chinese characteristics suitable for China's national conditions.

\section{REFERENCES}

[1] Li Manli, Zhang Yu, Ye Jingui, etc." decoding MOOC - a large scale online open course pedagogy expedition [M]. Beijing: Tsinghua University Press, 2014:2.

[2] Dictionary newsroom of the Institute of Language Studies of the Chinese Academy of Social Sciences. Modern English Dictionary (7th edition) [M]. Beijing: Commercial Press, 2016:1630.

[3] Kang Yeqin. SPOC analysis of the" post-MOOC era "of online education [J]. Educational research at Tsinghua University, 2014 (1) 87.

[4] Xi Jinping. Using the socialist thought of Chinese characteristics in the new era to cast the soul and educate and implement the party's educational policy to implement the Lides fundamental task [N] People's Daily, 2019-03-19. 